\title{
Aspirin inhibited the metastasis of colon cancer cells by inhibiting the expression of toll-like receptor 4
}

\author{
Suaka Kagbo-Kue ${ }^{*}$, Taiwo Ajose and Nicolas Bakinde
}

\section{Dear Editor,}

It was interesting to read the article Aspirin inhibited the metastasis of colon cancer cells by inhibiting the expression of toll-like receptor 4 published by Ying et al. Several studies have explored the mechanism of Aspirin in preventing colorectal cancer (CRC) and also that of metastases in CRC [1-4] but this study was noteworthy in that it explored the mechanism of Aspirin in preventing liver metastases in CRC.

According to the National Cancer Institute, CRC is the second leading cause of cancer deaths in the United States [5]. The liver is the most common site of metastases in CRC and significantly affects survival [6,7].

Aspirin is chemopreventive in different types of cancers especially CRC [1]. Tumorigenesis and CRC metastasis are hypothesized to occur by different mechanisms involving cancer stems cells (CSC), the overexpression of cyclooxygenase-2 (COX-2) and epidermal growth factor (EGFR), and other downstream effects in the early phases of CRC [2-4]; Aspirin is postulated to play its role by modifying these epigenetic events, especially among patients with mutated-PIK3CA [4]. Aspirin taken chronically at doses ranging from 75 to $200 \mathrm{mg}$ is associated with reduced mortality and increased survival $[3,4]$.

The results reported by the authors demonstrate that lipopolysaccharide (LPS) induced the metastasis and epithelial-mesenchymal transition (EMT) phenotype of colon cancer cells via a toll-like receptor 4 (TLR4) dependent manner. TLR4 thus mediates the biologic

*Correspondence: skagbokue@msm.edu

Department of Internal Medicine, Morehouse School of Medicine, Atlanta, USA function of LPS. Previous research has also indicated that LPS could activate the nuclear factor kappa B (NFkB) signal transduction which also plays a role in the EMT process [8]. LPS thus potentiated the metastatic potential of colon cancer cells in the cell lines in this study (C26 and HCT116). Treatment with Aspirin decreased TLR4 expression by decreasing LPS-induced EMT which further leads to downregulation of NFkB [7].

In agreement with the findings from the study, Aspirin might act as an inhibitor in the LPS-induced metastasis of colon cancer and TLR4 could be used as a prognostic marker and a potential therapeutic target [7]. Another class of drugs to consider is Statins. Statins have also been shown to inhibit LPS-induced EMT via the downregulation of TLR4 and NFkB in human biliary epithelial cells, and could be an additional agent for reducing the metastatic potential of colon cancer cells [9].

Based on this study, Aspirin is an inexpensive drug that could potentially reduce the mortality of CRC. Further studies are needed to explore the application to independent cohorts of patients, to validate that the potential benefits outweigh the possible risks, and to determine the role of other inexpensive drugs such as Statins, so as to increase survival in CRC.

\section{Authors' contributions}

All authors contributed in the body of the work by providing referenced material, writing and editing. All authors read and approved the final manuscript.

\section{Acknowledgements \\ Not applicable}

Competing interests

The authors declare that they have no competing interests.

Availability of data and materials

Not applicable. References are cited. 


\section{Consent for publication \\ Not applicable.}

\section{Declarations}

I declare that this is a letter to the editor and no human subject was used. Referenced materials have been cited and none of the contents of this letter are under consideration for publication in any other journal.

Ethics approval and consent to participate Not applicable.

\section{Funding}

We received no funding.

\section{Publisher's Note}

Springer Nature remains neutral with regard to jurisdictional claims in published maps and institutional affiliations.

Received: 1 March 2018 Accepted: 10 May 2018

Published online: 21 May 2018

\section{References}

1. Sostres C, Gargallo CJ, Lanas A. Aspirin, cyclooxygenase inhibition and colorectal cancer. World J Gastrointest Pharmacol Ther. 2014:5(1):40-9.
2. Wang H, Liu B, Wang J, et al. Reduction of NANOG mediates the inhibitory effect of aspirin on tumor growth and stemness in colorectal cancer. Cell Physiol Biochem. 2017;44(3):1051-63.

3. Di Francesco L, Lopez Contreras LA, Sacco A, Patrignani P. New insights into the mechanism of action of aspirin in the prevention of colorectal neoplasia. Curr Pharm Des. 2015;21(35):5116-26.

4. Liao X, Locchead P, Nishihara R, et al. Aspirin use, tumor PIK3CA mutation, and colorectal cancer survival. N Engl J Med. 2012;367:1596-606.

5. https://seer.cancer.gov/statfacts/html/colorect.html. Accessed 13 Feb 2018.

6. Sina V, Timothy JP, Christos SK. Colorectal cancer: metastases to a single organ. World J Gastroenterol. 2015;21(41):11767-76.

7. Ying J, Zhou HY, Liu P, You Q, Kuang F, Shen YN, Hu ZQ. Aspirin inhibited the metastasis of colon cancer cells by inhibiting the expression of toll-like receptor 4. Cell Biosci. 2018;8:1. https://doi.org/10.1186/s1357 8-017-0198-7.

8. Han M, Song Y, Zhang X. Quercetin suppresses the migration and invasion in human colon cancer Caco-2 cells through regulating toll-like receptor 4/nuclear factor-kappa B pathway. Pharmacogn Mag. 2016;12(Suppl 2):S237-44. https://doi.org/10.4103/0973-1296.182154 [Epub 2016 May 11]

9. Kim Y, Lee EJ, Jang HK, Kim CH, Kim DG, Han JH, Park SM. Statin pretreatment inhibits the lipopolysaccharide-induced epithelial mesenchymal transition via the downregulation of toll-like receptor 4 and nuclear factor-kB in human biliary epithelial cells. J Gastroenterol Hepatol. 2016:31(6):1220-8. https://doi.org/10.1111/jgh.13230.
Ready to submit your research? Choose BMC and benefit from

- fast, convenient online submission

- thorough peer review by experienced researchers in your field

- rapid publication on acceptance

- support for research data, including large and complex data types

- gold Open Access which fosters wider collaboration and increased citations

- maximum visibility for your research: over $100 \mathrm{M}$ website views per year

At $\mathrm{BMC}$, research is always in progress.

Learn more biomedcentral.com/submissions 